IJJM

Ilomata International Journal of Management

P-ISSN: 2714-8971; E-ISSN: 2714-8963

Vol. 1 No. 4 October 2020 pp.177-190

https://www.ilomata.org/index.php/ijim

\title{
Determining of The Compliance of Local Governments To Implement The Accounting System of The Government's Accrual Base In Indonesia
}

\author{
Agung Nur Probohudono'; Wahyu Widayat'; Siti Arifah ${ }^{3}$ \\ ${ }^{1}$ Universitas Sebelas Maret \\ ${ }^{2}$ BPKP Nusa Tenggara Barat \\ ${ }^{3}$ Universitas Tidar \\ Correspondent: anprobohudono@staff.uns.ac.id
}

Submitted : October 21, $2020 \quad$ Revised : October 25, $2020 \quad$ Published $\quad$ October 30, 2020

\begin{abstract}
This study refers to the influence of the age of local government, status, number of Regional Device Task Force (SKPD), financial autonomy ratios, effectiveness ratios, local income growth ratios, and the quality of local financial reports that exist in local governments as an independent variable on the compliance of local governments to implement government accounting systems as the dependent variable. Using quantitative methods with secondary data obtained from information on the publication of the Indonesian Financial Audit Agency, the Central Bureau of Statistics of the Republic of Indonesia (BPS), and local government reports. The sample used is limited to the municipal and district governments in western Indonesia, which are being evaluated by the Indonesian Financial Audit Agency in the implementation of an accrual base government accounting system of 158 local governments namely 36 cities and 122 districts. Multiple linear regression analysis was used to test the hypothesis. The research is a causality, quantitative research model, and secondary data from local governments throughout Indonesia and secondary data about the compliance of local governments in the application of Government Accounting Standards (SAP) published by the Audit Board of the Republic of Indonesia (BPK). The results of the hypothesis analysis conclude that the status of local government, the ratio of regional government autonomy, and the growth of local revenue significantly influence the compliance of local governments in the implementation of the accrual base government accounting system.
\end{abstract}

Keywords: Characteristics of Local Government, Local Government Finance Team, Local Government Report, Government System Base Accrual Base.

\section{INTRODUCTION}

The New Public Management Concept (NPM) in public accounting is seen as appropriate to be applied in order to help ensure that the objectives of government organizations can be achieved, especially with regard to external and internal accountability (Jorge de Jesus and Eirado, 2012). Good accountability will encourage maximum government allocation of resources (Adhikari et al., 2013). Improving the efficiency and quality of public services also requires innovation (Arundel et al., 2015). With the shift of paradigm in government sector management to NPM, the policies taken and their implementation need to be considered carefully (Kominis and Dudau, 2012). So reforms are needed towards government/public modernization (Almquist et al, 2013).

Some countries have largely changed their accounting systems to an accrual base 
Determining of The Compliance of Local Governments To Implement The Accounting System of The Government's Accrual Base In Indonesia

Probohudono, Widayat, \& Arifah

accounting system that originally used a cash base accounting system. Changes in the application of this accrual base accounting system are becoming an ongoing trend internationally (Lüder et al., 2003). The basic assumption used is that accounting standards govern accounting practices, but accounting is a social system that has a tendency to evolve according to the environmental context (Bergevärn et al., 1995).

Positive accounting theory assumes that the relative strength between the agent and the principal affects the choice and use of accounting methods. An agency issue will arise in the context of the organization, both commercial and political (Zimmerman, 1977). Politicians feel the need to take into account voters and other stakeholders in order to fulfil their ambitions for re-election (Downs, 1957).

The policy of implementing accounting and managerial systems in the public sector is often influenced by reforms and shifts in political power (Chang, 2009; Alawattage et al., 2007). In the Indonesian public sector, the reforms resulted in the emergence of a decentralization movement of local government management as well as improved quality of reporting in the public sector (Bell et al., 2012). In accordance with the legislation passed after 1998, the change made at the time was to create greater independence for the Local Government and be obliged to compile reports that conformed to accounting standards inspired by international accounting standards. Many government initiatives adopt these standards from the Asian Development Bank (ADB) and the World Bank including the International Monetary Fund (IMF) as guidelines for drafting policies designed in order to achieve better and transparent governance. The implementation of accrual base accounting systems in the Indonesian public sector was part of an international trend at the time to ensure that responsible officials had used public money efficiently and effectively (Saleh and Pendlebury, 2006; Ryan, 1999; Guthrie, 1998; Alam, 1997).

Some studies of public accounting reform in developed countries illustrate there is no significant benefit from the application of accounting on that accrual base (Christensen, 2007; Connolly and Hyndman, 2006; Carlin, 2005). In some objects, the shift in the application of accounting systems has had a detrimental impact (Bell et al., 2009; Andon et al., 2007; Othman et al., 2006; Kamal Hassan, 2005; Vámosi, 2000). An example is the adoption of an activity-based financing system in the public sector in Portugal rejected by workers (Bell et al., 2009). A similar problem occurred in public sector organizations in Malaysia where changes to the accounting system resulted in conflicts and tensions between workers (Nor-Aziah and Scapens, 2007).

The application of accounting techniques similar to the style of the business sector does not guarantee that efficiency, transparency or effectiveness will occur (Chow et al., 2009). When the rules on accounting reporting system change, a new type of report will be generated, however, the change does not always improve the attitudes and behavior of people using the new system (Ter Bogt and Van Helden, 2000). So it is important to look at the application of a private sector-style accounting system not only as an instrument, but also to understand it in a comprehensive managerial, organizational and social context (Bale and Dale, 1998).

The application of accounting systems such as in the private sector cannot necessarily be used as a way to achieve the goals of public accounting reform (Christensen and Parker, 2010; Arnaboldi and Lapsley, 2009; Christiaens and Rommel, 2008; Christensen. Government officials and professional accountants often advocate the movement globally adopting accrual base accounting in the public sector unsupported by the presence of a strong theoretical base and proper empirical studies (Carlin, 2005). A number of problems contributed to the slow implementation of accrual accounting in the public sector. This includes setting financial 
Determining of The Compliance of Local Governments To Implement The Accounting System of The Government's Accrual Base In Indonesia

Probohudono, Widayat, \& Arifah

reporting rules where there is a disharmony of relations between the central government and the Local Government. Inappropriate human resource management/management system in the state of central government and local government (Harun, 2007; Nor Aziah and Scapens, 2007); and there are still concerns over the benefits of using accrual systems in order to eradicate corruption or public management interests (Shiraz Rahaman, 2009; Connolly and Hyndman, 2006).

This perspective is important to remind that policymakers should prioritize their strategies for designing effective support programs, given that the implementation of accrual bases on public accounting is complex and expensive (Pilcher and Dean, 2009). Accountability and performance of public organizations especially in developing countries cannot be achieved automatically by issuing new laws and private sector-style reporting standards, and accrual base reports.

The implementation of accrual accounting on public entities still requires the hard work of all relevant parties due to measurement problems and the lack of theoretical support that the expected benefits are still more significant compared to the shortcomings (Chan, 2003). These benefits include improved financial condition of public sector organizations (Guthrie, 1998), increased transparency and financial accountability (Ryan, 1998; Perrin, 1998; Gillibrand and Hilton, 1998), improving organizational performance (Likierman, 2000; Christiaens and Wielemaker, 2003), improved towards better decisions taken in terms of resource allocation/sharing (Pallot, 1997; Hoque and Moll, 2001; Goldman and Brashares, 1991), more accurate measurement of performance and calculation of service charges (Hodges and Mellett, 2003; Pallot, 2001).

There are 3 (three) local governments in Indonesia (Tangerang City, Palu City, and Bima Regency) with two main problems faced during the implementation process: (1) the submission of responsibilities that are not accompanied by the surrender of authority related to her management (staffing) and (2) regulations from the central government that are out of sync and often change. Thus the impact or consequences of the problem include: (1) low level of Regional Government Financial Reports (LKPD) conformity to Government Accounting Standards (SAP) and (2) low utilization rate of Regional Government Financial Reports (LKPD) for decision making (McLeod and Harun, 2014).

Meanwhile, there are three local governments in Indonesia (Jakarta Province, Tangerang City and Pandeglang Regency) with the failure of reform initiatives in achieving the goal of increasing transparency and accountability. Where there are most government agencies with the status of opinion scoring financial statements "Reasonable With Exceptions" or "No Opinion" from the Audit Board of the Republic of Indonesia (BPK) (Mir and Sutiyono, 2013). The cause of the failure was an imbalance between the request and the provision of quality accounting information. Requests for accounting information in the public sector in Indonesia are only pseudo where public sector executives request accounting information but do not use it as a base in decision making. While the problems in the process of providing accounting information are closely related to the limited number of professional public sector accountants (Mir and Sutiyono, 2013).

The Government of Indonesia continues to pursue reforms in the field of state financial management through the publication of a package of regulations including Law No. 17 of 2003 on State Finance, Law No. 1 of 2004 on The Treasury, and Law No. 15, 2004 on Examination of State Financial Management and Responsibility. The publication of this package of laws is aimed 
Determining of The Compliance of Local Governments To Implement The Accounting System of The Government's Accrual Base In Indonesia

Probohudono, Widayat, \& Arifah

at realizing good governance with increasing professionalism, accountability, and transparency in the framework of implementation and State Financial Responsibility. The publication of this package of laws is aimed at realizing good governance with increasing professionalism, accountability, and transparency in the framework of the implementation and management of state finances.

Furthermore, the government issued PP No. 24 of 2005 on SAP (Government Accounting Standards) and PP No. 58 of 2005 on Regional Financial Management. The two PP became the basic guidelines in the management of the government's financial accounting in the year to 2010 . The accrual base accounting system was implemented based on PP No. 71 of 2010 on Government Accounting Standards (SAP) replacing PP No. 24 of 2005, and in 2014 was set as the deadline for Government Accounting Standards (SAP) implementation preparation of accrual base. As of January 1, 2015, all ministries or institutions and local governments in Indonesia must implement Government Accounting Standards (SAP) accrual base. With the implementation of full accrual base accounting is expected to encourage the realization of effective, accountable, and transparent state financial management (Hyndman and Connolly, 2011).

The target of fair opinion without exception (WTP) that has not been reached for Regional Government Financial Reports (LKPD) in 2014 describes the condition that the majority of local governments have not been able to meet Government Accounting Standards (SAP) cash base towards accruals. Most of the government's existing financial/accounting managers have not mastered the concept of accounting the cash base towards accruals making it difficult to understand the accounting system of the full accrual base (Becker et al., 2014). So in 2015 there are still many local governments that are not ready to fully implement the accounting system on an accrual base.

This research is limited to obtaining empirical evidence in order to know the things that affect the compliance of the local government to implement the accounting system of the accrual base, all local governments in Indonesia. The discussion is limited to testing to analyze how the characteristics, financial performance, and quality of the local government's financial statements affect the level of compliance of the Local Government to implement accounting standards based on PP No. 71 of 2010 which must be applied starting in 2015.

A transition period of 5 years was given to the local government, namely from 2010 to 2014, to prepare everything necessary related to the implementation of the accrual base accounting system. However, most local governments are still not fully able to implement the standard accounting cash base towards accruals, proven that many local governments have not been able to get opinion without exception (WTP) from Audit Board of the Republic of Indonesia (BPK). The compliance of the local government in this case can be influenced by several factors including the characteristics, financial performance, and quality of the local government's financial statements. So from these factors are expected to be sought the right solutions and follow-up steps in order to anticipate obstacles and optimize the capabilities or advantages of each local government. The capabilities, advantages, and obstacles of course differ in each local government so that the concrete follow-up steps and solutions offered should be different according to the conditions faced by the Local Government (Gårseth-Nesbakk, 2011).

The success rate in the implementation of accrual base accounting for each local government gives different results. This can be influenced by characteristics reflected in an organization's ability to deal with problems that occur in each region (Liguori and Steccolini, 
Determining of The Compliance of Local Governments To Implement The Accounting System of The Government's Accrual Base In Indonesia

Probohudono, Widayat, \& Arifah

2011). The length of time the Local Government organization was formed since it was founded was used in this study as a variable of the administrative life of the Local Government by the count of years. The administrative age of this local government is calculated based on the local government establishment law. Local governments with more administrative age should have more ability and experience in presenting financial statements according to Government Accounting Standards (SAP).

In the implementation of its operations the Local Government organization is divided into several sub units with different functional differentiations called SKPD (Regional Device Task Force) (Suhardjanto and Yulianingtyas, 2011). Functionally housed in Regional Device Task Force (SKPD) is a means of operationally sharing information, ideas, and innovation (Damanpour, 1991) in order to help the task of the regional head. The existence of Regional Device Task Force (SKPD) in a more complex area should encourage the ability of local governments to better implement accounting systems. The variable complexity of local governments in this study used a measure of the number of Regional Device Task Force (SKPD).

A district or city is the status of recognition of an area based on the division of administrative regions applicable in Indonesia, below the provincial level. The district or city in general has the same authority that is to regulate and manage its own government. Perception of regional status affects the compliance of local governments to implement Government Accounting Standards (SAP) accruals due to differences in quantity and competence/quality of state civil servants/apparatuses (ASN) in each local government. In general, infrastructure, as well as information technology applied to the city government is better and more complete than the district government.

Financial performance, innovation, customer satisfaction, and employee performance are often used as a measure in the majority of local governments of Canada and the United States (Lilian Chan, 2004). Problems in measuring public sector performance arise due to differences in requirements as a result of conflicting stakeholder needs (Mettänen, 2005; Wisniewski and Stewart, 2004; Lawton et al, 2000). Performance measurement should be applied to all levels of government organizations by providing valuable information about the most important performance dimensions (Rantanen et al., 2007).

Performance measures against public sector organizations in recent years have gained the attention of many researchers. The proposed language includes the organization of real estate corporations (Wilson et al., 2004) measurement design (Wisniewski and Ólafsson, 2004), the use of measurement tools (; Wilson et al., 2004), implementation (Collier, 2006; Shih-Jen and YeeChing, 2002), essence in performance measurement system (Van Peursem et al., 1995). Research on performance measurement in other public organizations including in the field of health care (Modell, 2001; Brignall and Modell, 2000; Van Peursem et al., 1995), police agencies (Collier, 2006), universities/higher education (Modell, 2003), and local government (Shih-Jen and YeeChing, 2002). The study largely illustrates the balance in measuring the performance of public sector organizations in both financial and non-financial fields, and provides an overview of the differences in performance measurement between public sector organizations and private organizations (Brignall and Modell, 2000; Guthrie and English, 1997).

A region's reliance on external sources of funds (central and provincial governments) is illustrated by the ratio of regional self-reliance. The greater the independence ratio means the regional dependence on external funds is lower, and vice versa. The self-reliance ratio reflects the 
Determining of The Compliance of Local Governments To Implement The Accounting System of The Government's Accrual Base In Indonesia

Probohudono, Widayat, \& Arifah

strength of community participation through the payment of taxes and regional levies to form locally-generated revenue (PAD) figures. The high level of public welfare can indicate the compliance of the local government in implementing Government Accounting Standards (SAP) accrual base.

The ability of the local government to realize locally-generated revenue (PAD) based on the real potential of the region is reflected through the effectiveness ratio number (Halim, 2012). The potential of this area differs from one local government and another, which in this case depends on various factors such as the geographical condition of the region and the natural wealth it has. The high effectiveness ratio of an area can indicate the compliance of the local government in implementing Government Accounting Standards (SAP) accrual base.

The capacity of local governments to maintain even improved success in some periods is reflected through the growth ratio figures. Growth in each component of expenditure and revenue source is used to determine the focus of attention on the potential of the region (Halim, 2012). The higher the growth ratio reflecting the level of regional capability can indicate the compliance of the local government in implementing Government Accounting Standards (SAP) accrual base.

In literature there is universal recognition that annual reports are one of the main instruments of accountability within the organization (Hyndman and Connolly, 2011). The preparation of the annual report can be seen as a cycle of accountability completion that begins with the budgeting process (English, 2003).

The annual report also provides mechanisms for publishing performance information on the efficiency and effectiveness of operations (Rutherford, 2000). The annual reports of public organizations can be classified into two: the annual report section presented to the examiner focusing on the formalities of the annual report (Anthony, 1978) and the annual report section presented to decision makers, which focuses on the content of the annual report (Atamian and Ganguli, 1991).

Some research suggests that internal groups of the public sector (including ministers, parliaments, and department heads) should take precedence over users of annual reports, then external stakeholders (Atamian and Ganguli, 1991). While other literature concludes that many departments do not publish information on progress in achieving established goals, performance information, or responses to auditors' findings, annual reports are inadequate to audit, and neither the cash accounting base nor the accrual accounting base is sufficient to account for accountability (Parker and Guthrie, 1993).

Hoque examined annual reporting practices in four departments that are public sector organizations in Australia, finding that reporting requirements were the main determinant of the content of the report (Hoque, 2008). Other research notes that public and private sector annual reports are essentially the same format (Stanton and Stanton, 2002), and there is no fundamental difference between public and private sector financial reporting (Mack and Ryan, 2006), so that public sector annual reports are mostly used only as a legitimacy tool (Ryan et al., 2002). The higher government accountability that reflects the level of quality of its financial statements indicates the government's ability to implement an accrual base accounting system.

\section{METHODS}

The research method used is quantitative with causal research design. The research model tests the influence on the administrative life of the local government, the number of Regional 
Determining of The Compliance of Local Governments To Implement The Accounting System of The Government's Accrual Base In Indonesia

Probohudono, Widayat, \& Arifah

Device Task Force (SKPD), regional status, local government independence ratio, locallygenerated revenue (PAD) effectiveness ratio, locally-generated revenue (PAD) growth ratio, and the quality of local government financial statements as independent variables on the compliance of local governments to implement Government Accounting Standards (SAP) accrual base as dependent variables. Furthermore, the local government measure (size) and human development index (IPM) are used as control variables.

Local Government, Central Bureau of Statistics (BPS), and Audit Board of the Republic of Indonesia (BPK) publications are the sources for which secondary data in this study was obtained. All local governments in Indonesia are populations in research and samples taken with purposive sampling method with the following criteria: (1) The city/district government issued Regional Government Financial Reports (LKPD) and has conducted Audit Board of the Republic of Indonesia (BPK) audits for 2013 and 2014; and (2) City/district governments that have been evaluated by the Audit Board of the Republic of Indonesia (BPK) for the process of preparing the implementation of the accrual base accounting system.

The compliance of local governments in implementing Government Accounting Standards (SAP) accrual base is demonstrated by data sourced from Audit Board of the Republic of Indonesia (BPK) on Regional Government Financial Reports (LKPD) inspection for 2014. In the report the results of the examination are presented the results of the evaluation of the compliance of the Local Government in implementing the accrual base accounting system for the following eight aspects: (1) competence and distribution of human resources in the financial; (2) socialization of PP No. 71 of 2010; (3) activities (education and training); (4) preparation of regional regulations on accounting and Government Accounting Standards (SAP) policies in the region; (5) compliance with the structure of local government organizations; (6) application in the form of applications in integrated regional financial management; (7) adequate allocation of budget/cost planning; and (8) development/improvement of the regional financial management system.

The results of Audit Board of the Republic of Indonesia (BPK) evaluation in the form of narratives about the above aspects are then quantified by content analysis method so as to produce the number of local government compliance index in implementing accrual base accounting system on December 31, 2014.

Data on financial independence ratio, locally-generated revenue (PAD) effectiveness ratio, and locally-generated revenue (PAD) growth ratio are in the form of processing ratios conducted by the authors where the main data sources are sourced from the financial statements of the local government as of December 31, 2013 and December 31, 2014 respectively. Meanwhile, the quality data of local government financial statements in the form of secondary data in the form of index figures of content analysis processing results conducted by the author where the main data source is a list of reasonable and unnatural accounts contained in the attachment of Audit Board of the Republic of Indonesia (BPK) examination results for fiscal year 2014.

Data size in the form of secondary data that refers to the size of assets owned by the Local Government and presented in the financial statements of each local government as of December 31, 2014. Meanwhile, human development index (IPM) data was obtained from bps publication for 2014. 
Determining of The Compliance of Local Governments To Implement The Accounting System of The Government's Accrual Base In Indonesia

Probohudono, Widayat, \& Arifah

Table 1.

Operational Variable Definitions

\begin{tabular}{|c|c|c|c|c|c|}
\hline No & Symbol & Variable & $\begin{array}{l}\text { Operational/Word } \\
\text { (Operational) }\end{array}$ & Medium Scale & Source \\
\hline \multicolumn{6}{|c|}{ Independent Variables } \\
\hline 1 & Age & Age & $\begin{array}{l}\text { the months of the } \\
\text { election of Sekda }\end{array}$ & $\begin{array}{l}\text { Ratio scale: a } \\
\text { number of years }\end{array}$ & $\begin{array}{l}\text { Local } \\
\text { Government } \\
\text { Law Form }\end{array}$ \\
\hline 2 & SKPD & $\begin{array}{l}\text { Number of } \\
\text { SKPD }\end{array}$ & $\begin{array}{l}\text { Number of SKPD in } \\
\text { Local Government }\end{array}$ & $\begin{array}{l}\text { Ratio scale: use the } \\
\text { number of SKPD }\end{array}$ & $\begin{array}{l}\text { LKPD } \\
\text { Audited }\end{array}$ \\
\hline 3 & Status & Status area & $>$ District or city & $\begin{array}{l}\text { Ordinal scale: } \\
\text { (district:1 or city: } 2 \text { ) }\end{array}$ & $\begin{array}{l}\text { Local } \\
\text { Government } \\
\text { Law Form }\end{array}$ \\
\hline 4 & $\begin{array}{l}\text { Independen } \\
\text { ce }\end{array}$ & $\begin{array}{l}\text { Self-reliance } \\
\text { ratio }\end{array}$ & $\begin{array}{l}\text { Ratio of local } \\
\text { government financial } \\
\text { independence meter }\end{array}$ & Ratio scale: 000,000 & $\begin{array}{l}\text { LKPD } \\
\text { Audited }\end{array}$ \\
\hline 5 & Kemusyi & $\begin{array}{l}\text { Ratio to a } \\
\text { PAD }\end{array}$ & $\begin{array}{l}\text { PAD target mecteri } \\
\text { number meter ratio }\end{array}$ & Ratio scale: 000,000 & $\begin{array}{l}\text { LKPD } \\
\text { Audited }\end{array}$ \\
\hline 6 & $\begin{array}{l}20,2014 \text { in } \\
\text { New }\end{array}$ & $\begin{array}{l}\text { PAD growth } \\
\text { ratio }\end{array}$ & $\begin{array}{l}\text { Number meter ratio } \\
\text { improves PAD disal }\end{array}$ & Ratio scale: 000,000 & $\begin{array}{l}\text { LKPD } \\
\text { Audited }\end{array}$ \\
\hline 7 & Bermusying & LKPD Level & $>$ LKPD Entry Level & $\begin{array}{l}\text { Ratio scale: use } \\
\text { index assets over } \\
\text { reasonable accounts } \\
\text { on LKPD }\end{array}$ & $\begin{array}{l}\text { IHPS } \\
\text { Semester I } \\
\text { Year } 2015 \\
\text { BPK RI }\end{array}$ \\
\hline \multicolumn{6}{|c|}{ Dependent Variables } \\
\hline 8 & Compliance & $\begin{array}{l}\text { SAP accrual } \\
\text { implementatio } \\
\text { n compliance }\end{array}$ & $\begin{array}{l}\text { Compliance to } \\
\text { multiply SAP accruals }\end{array}$ & $\begin{array}{l}\text { Ratio scale: use \% } \\
\text { compliance over } \\
\text { aspect }\end{array}$ & $\begin{array}{l}\text { LHA BPK- } \\
\text { RI }\end{array}$ \\
\hline \multicolumn{6}{|c|}{ Control Variables } \\
\hline 9 & Size & $\begin{array}{l}\text { Local } \\
\text { Government } \\
\text { Size }\end{array}$ & $\begin{array}{l}\text { The amount of assets } \\
\text { that the local } \\
\text { government }\end{array}$ & $\begin{array}{l}\text { Ratio scale: use the } \\
\text { amount of local } \\
\text { government assets }\end{array}$ & $\begin{array}{l}\text { LKPD } \\
\text { Audited }\end{array}$ \\
\hline 10 & Ipm & $\begin{array}{l}\text { Human } \\
\text { Developmen } \\
\text { t Index }\end{array}$ & $\begin{array}{l}\text { Ratio of human } \\
\text { development } \\
\text { measuring measures } \\
\text { based on basic living } \\
\text { components }\end{array}$ & $\begin{array}{l}\text { Ratio scale: index } \\
\text { 0000-none }\end{array}$ & Bps \\
\hline
\end{tabular}

\section{RESULTS AND DISCUSSION}

The results of normality tests, heteroskedasticity tests, and multicollinearity tests that are part of the classic assumption test show the research data has normal distribution as well as no multicollinearity as well as heteroskedastic problems in the research data tested.

Determination coefficient tests, F-tests, and t-tests are performed to test hypotheses to find out how dependent variables are affected by independent variables. Adjusted R Square's figure of 0.197 from the determination coefficient test results means only $19.7 \%$ of independent variables can explain the government's compliance in implementing Government Accounting Standards (SAP) accruals. The remaining $80.3 \%$ is explained by variables other than those used in this research model.

Simultaneous tests (f-test) giving a value of $F=5,290$ at a value of $F$ significance $=0.000$ or in other words F sig $<0.05$ indicate that the model structured in the regression equation is 
Determining of The Compliance of Local Governments To Implement The Accounting System of The Government's Accrual Base In Indonesia

Probohudono, Widayat, \& Arifah

feasible to test how the influence of independent variables to dependent variables. While the partial test results ( $\mathrm{t}$-test) show the following numbers:

Table 2.

Partial Test Result

\begin{tabular}{lllll}
\hline Variable & $\mathbf{B}$ & Std.Error & $\mathbf{Q}$ & Sig. \\
\hline (Constants) & 72,849 & 72,882 & 1,000 & 0,319 \\
\hline Age & 0,049 & 0,072 & 0,678 & 0,499 \\
\hline SKPD & 0,079 & 0,104 & 0,758 & 0,449 \\
\hline Status & 12,590 & 5,038 & 2,499 & $0,014^{*}$ \\
\hline Independence & 0,321 & 0,137 & 2,341 & $0,021^{*}$ \\
\hline kemuderan & 0,052 & 0,085 & 0,608 & 0,544 \\
\hline 2002 & $-0,0570$ & 0,023 & $-2,502$ & $0,013^{*}$ \\
\hline Both & 0,141 & 0,075 & 1,877 & 0,062 \\
\hline ln_size & $-0,7360$ & 2,318 & $-0,3170$ & 0,751 \\
\hline Ipm & $-0,3810$ & 0,463 & $-0,8210$ & 0,413 \\
\hline
\end{tabular}

$*=$ average at alpha $5 \%$

Regression coefficient for age variables, number of Regional Device Task Force (SKPD), status, independence, effectiveness, and quality of positive value $(+)$. Thus the older the administrative age of the local government, the more complex the local government, the higher the independence ratio, the higher the effectiveness ratio of locally-generated revenue (PAD), and the higher the quality of Regional Government Financial Reports (LKPD), the higher the compliance of the local government in implementing Government Accounting Standards (SAP) accrual base. It can also be seen that it is better to be prepared for local government with city status compared to local government with district status in implementing Government Accounting Standards (SAP) accrual base.

The regression coefficient of negative value growth $(-)$ means the higher the locallygenerated revenue (PAD) growth ratio then the lower the government's compliance in implementing Government Accounting Standards (SAP) accrual base.

Local Government status variables, local government financial independence ratios, and locally-generated revenue (PAD) growth ratios have a partially significant influence on local government compliance in implementing Government Accounting Standards (SAP) accruals. With the significance of $<0.05$ means higher independence ratio and lower locally-generated revenue (PAD) growth ratio partially increases the compliance of local government to implement Government Accounting Standards (SAP) accrual base.

Based on partial test results only Hypothesis 3 and Hypothesis 4 are supported, i.e. there is a positive influence on the status of local government and the ratio of independence to compliance of local government implementing the accounting system on an accrual base, with a value of significance of $t$ count $<0.05$.

Simultaneous test results also showed that independent variables had a simultaneous influence on dependent variables with an influence rate of only $19.7 \%$. Such conditions may be due to the following:

a. Implementation towards Government Accounting Standards (SAP) accrual base is new for all local governments so there is no difference between the newly established government and the long-established local government. 
Determining of The Compliance of Local Governments To Implement The Accounting System of The Government's Accrual Base In Indonesia

Probohudono, Widayat, \& Arifah

b. The complexity of the local government reflected in the number of Regional Device Task Force (SKPD) does not affect the compliance of the local government to implement Government Accounting Standards (SAP) accrual base where the implementation process is carried out in unison for all Regional Device Task Force (SKPD) in Indonesia regardless of the number of Regional Device Task Force (SKPD) that exists. So the hope of the emergence of new ideas and innovations in Regional Device Task Force (SKPD) in implementing Government Accounting Standards (SAP) accruals did not occur.

c. The ability of the Local Government to realize locally-generated revenue (PAD) targets indicated by the effectiveness ratio is not in line with the compliance of the local government to implement Government Accounting Standards (SAP) accrual base.

d. The significance value of 0.072 for the quality of the local government's financial statements does not affect the compliance of the local government to implement Government Accounting Standards (SAP) accrual base

\section{CONCLUSION}

The administrative age of the local government, the number of Regional Device Task Force (SKPD), regional status, independence ratio, locally-generated revenue (PAD) effectiveness ratio, and locally-generated revenue (PAD) growth ratio, as well as the quality of the local government's financial statements simultaneously have an influence on the variable compliance of the local government to implement Government Accounting Standards (SAP) accrual base.

Regional status, independence ratio, and locally-generated revenue (PAD) growth ratio individually have an influence on the compliance of local governments to implement Government Accounting Standards (SAP) accrual base. The city government has a higher compliance to implement Government Accounting Standards (SAP) accrual base than the district government.

This study has limitations such as: (1) the sample assigned only to city and district governments with sap implementation compliance level of accrual base has been evaluated Audit Board of the Republic of Indonesia (BPK); and (2) the research data used was only Regional Government Financial Reports (LKPD) as of December 31, 2014.

The results of this study are expected to contribute to the central government, local governments, researchers and academics related to the image of local governments in accepting and implementing new regulations. This is useful when the state will make new regulations regarding financial governance, for example to adapt to the era of society 5.0.

\section{REFERENCES}

Adhikari, P., C. Kuruppu, and S. Matilal. (2013). Dissemination and institutionalization of public sector accounting reforms in less developed countries: A comparative study of the Nepalese and Sri Lankan central governments. Accounting Forum 37 (3):213-230.

Alam, M. (1997). Budgetary process in uncertain contexts: a study of state-owned enterprises in Bangladesh. Management Accounting Research 8 (2):147-167.

Alawattage, C., T. Hopper, D. Wickramasinghe, N. Putu S, G. Jan van Helden, and S. Tillema. (2007). Public sector performance measurement in developing countries: A literature review and research agenda. Journal of Accounting \& Organizational Change 3 (3):192-208. 
Determining of The Compliance of Local Governments To Implement The Accounting System of The Government's Accrual Base In Indonesia

Probohudono, Widayat, \& Arifah

Almquist, R., G. Grossi, G. J. van Helden, and C. Reichard. (2013). Public sector governance and accountability. Critical Perspectives on Accounting 24 (7-8):479-487.

Andon, P., J. Baxter, and W. F. Chua. (2007). Accounting change as relational drifting: A field study of experiments with performance measurement. Management Accounting Research 18 (2):273-308.

Anthony, R. N. (1978). Financial accounting in nonbusiness organizations: an exploratory study of conceptual issues: Financial Accounting Standards Board.

Arnaboldi, M., and I. Lapsley. (2009). On the implementation of accrual accounting: a study of conflict and ambiguity. European Accounting Review 18 (4):809-836.

Arundel, A., L. Casali, and H. Hollanders. (2015). How European public sector agencies innovate: The use of bottom-up, policy-dependent and knowledge-scanning innovation methods. Research Policy 44 (7):1271-1282.

Atamian, R., and G. Ganguli. (1991). The recipients of municipal annual financial reports: a nationwide survey. The Journal of Government Financial Management 40 (3):3.

Bale, M., and T. Dale. (1998). Public sector reform in New Zealand and its relevance to developing countries. The World Bank Research Observer 13 (1):103-121.

Becker, S. D., T. Jagalla, and P. Skærbæk. (2014). The translation of accrual accounting and budgeting and the reconfiguration of public sector accountants' identities. Critical Perspectives on Accounting 25 (4-5):324-338.

Bell, J., Z. Hoque, H. Harun, K. Van Peursem, and I. Eggleton. (2012). Institutionalization of accrual accounting in the Indonesian public sector. Journal of Accounting \& Organizational Change 8 (3):257-285.

Bell, J., Z. Hoque, M. A. Norhayati, and A. K. Siti-Nabiha. (2009). A case study of the performance management system in a Malaysian government linked company. Journal of Accounting \& Organizational Change 5 (2):243-276.

Bergevärn, L.-E., F. Mellemvik, and O. Olson. (1995). Institutionalization of municipal accounting - a comparative study between Sweden and Norway. Scandinavian Journal of Management 11 (1):25-41.

Brignall, S., and S. Modell. (2000). An institutional perspective on performance measurement and management in the 'new public sector'. Management Accounting Research 11 (3):281-306.

Carlin, T. M. (2005). Debating the impact of accrual accounting and reporting in the public sector. Financial Accountability \& Management 21 (3):309-336.

Chan, J. L. (2003). Government accounting: an assessment of theory, purposes and standards. Public Money \& Management 23 (1):13-20.

Chang, L. c. (2009). The impact of political interests upon the formulation of performance measurements: the NHS star rating system. Financial Accountability \& Management 25 (2):145-165.

Chow, D., C. Humphrey, and J. Moll. (2009). New development: In pursuit of WGA-Research findings from the UK. Public Money \& Management 29 (4):257-260.

Christensen, M. (2007). What We Might Know (But Aren't Sure) About Public-Sector Accrual Accounting. Australian Accounting Review 17 (41):51-65.

Christensen, M., and L. Parker. (2010). Using ideas to advance professions: public sector accrual accounting. Financial Accountability \& Management 26 (3):246-266. 
Determining of The Compliance of Local Governments To Implement The Accounting System of The Government's Accrual Base In Indonesia

Probohudono, Widayat, \& Arifah

Christiaens, J., and J. Rommel. (2008). Accrual accounting reforms: only for businesslike (parts of) governments. Financial Accountability \& Management 24 (1):59-75.

Christiaens, J., and E. D. Wielemaker. (2003). Financial accounting reform in Flemish universities: an empirical study of the implementation. Financial Accountability \& Management 19 (2):185-204.

Collier, P. M. (2006). Costing police services: The politicization of accounting. Critical Perspectives on Accounting 17 (1):57-86.

Connolly, C., and N. Hyndman. (2006). The actual implementation of accruals accounting: caveats from a case within the UK public sector. Accounting, Auditing \& Accountability Journal 19 (2):272-290.

Damanpour, F. (1991). Organizational Innovation: A Meta-Analysis of Effects of Determinants and Moderators. The Academy of Management Journal 34 (3):555-590.

Downs, A. (1957). An Economic Theory of Democracy: Harper.

English, L. (2003). Emasculating public accountability in the name of competition: transformation of state audit in Victoria. Critical Perspectives on Accounting 14 (1):51-76.

Gårseth-Nesbakk, L. (2011). Accrual accounting representations in the public sector-A case of autopoiesis. Critical Perspectives on Accounting 22 (3):247-258.

Gillibrand, A., and B. Hilton. (1998). Resource accounting and budgeting: principles, concepts and practice - the MoD case. Public Money and Management 18 (2):21-28.

Goldman, F., and E. Brashares. (1991). Performance and accountability: Budget reform in New Zealand. Public Budgeting \& Finance 11 (4):75-85.

Guthrie, J. (1998). Application of accrual accounting in the Australian public sector-rhetoric or reality. Financial Accountability \& Management 14 (1):1-19.

Guthrie, J., and L. English. (1997). Performance information and programme evaluation in the Australian public sector. International Journal of Public Sector Management 10 (3):154-164.

Halim, A. (2012). Akuntansi keuangan daerah: akuntansi sektor publik.

Harun. (2007). Obstacles to public sector accounting reform in Indonesia. Bulletin of Indonesian Economic Studies 43 (3):365-376.

Hodges, R., and H. Mellett. (2003). Reporting public sector financial results. Public Management Review 5 (1):99-113.

Hoque, Z. (2008). Measuring and reporting public sector outputs/outcomes: Exploratory evidence from Australia. International Journal of Public Sector Management 21 (5):468-493.

Hoque, Z., and J. Moll. (2001). Public sector reform-Implications for accounting, accountability and performance of state-owned entities-an Australian perspective. International Journal of Public Sector Management 14 (4):304-326.

Hyndman, N., and C. Connolly. (2011). Accruals accounting in the public sector: A road not always taken. Management Accounting Research 22 (1):36-45.

Jorge de Jesus, M. A., and J. S. B. Eirado. (2012). Relevance of accounting information to public sector accountability: A study of Brazilian federal public universities. Tékhne 10 (2):87-98.

Kamal Hassan, M. (2005). Management accounting and organisational change: an institutional perspective. Journal of Accounting \& Organizational Change 1 (2):125-140.

Kominis, G., and A. I. Dudau. (2012). Time for interactive control systems in the public sector? The case of the Every Child Matters policy change in England. Management Accounting Research 23 (2):142-155. 
Determining of The Compliance of Local Governments To Implement The Accounting System of The Government's Accrual Base In Indonesia

Probohudono, Widayat, \& Arifah

Lawton, A., D. McKevitt, and M. Millar. (2000). Developments: Coping with ambiguity: Reconciling external legitimacy and organizational implementation in performance measurement. Public Money and Management 20 (3):13-20.

Liguori, M., and I. Steccolini. (2011). Accounting change: explaining the outcomes, interpreting the process. Accounting, Auditing \& Accountability Journal 25 (1):27-70.

Likierman, A. (2000). Changes to managerial decision-taking in UK central government. Management Accounting Research 11 (2):253-261.

Lilian Chan, Y.-C. (2004). Performance measurement and adoption of balanced scorecards: a survey of municipal governments in the USA and Canada. International Journal of Public Sector Management 17 (3):204-221.

Lüder, K., A. G. Zürich Price Waterhouse Coopers, and R. Jones. (2003). Reforming Governmental Accounting and Budgeting in Europe: Fachverlag Moderne Wirtschaft.

Mack, J., and C. Ryan. (2006). Reflections on the theoretical underpinnings of the generalpurpose financial reports of Australian government departments. Accounting, Auditing \& Accountability Journal 19 (4):592-612.

McLeod, R. H., and H. Harun. (2014). Public Sector Accounting Reform at Local Government Level in Indonesia. Financial Accountability \& Management 30 (2):238-258.

Mettänen, P. (2005). Design and implementation of a performance measurement system for a research organization. Production Planning \& Control 16 (2):178-188.

Mir, M., and W. Sutiyono. (2013). Public Sector Financial Management Reform: A Case Study of Local Government Agencies in Indonesia. Australasian Accounting Business \& Finance Journal 7 (4):97.

Modell, S. (2001). Performance measurement and institutional processes: a study of managerial responses to public sector reform. Management Accounting Research 12 (4):437-464. . (2003). Goals versus institutions: the development of performance measurement in the Swedish university sector. Management Accounting Research 14 (4):333-359.

Nisfiannoor, M. (2009). Pendekatan statististika Modern untuk Ilmu Sosial: Penerbit Salemba.

Nor-Aziah, A. K., and R. W. Scapens. (2007). Corporatisation and accounting change: The role of accounting and accountants in a Malaysian public utility. Management Accounting Research 18 (2):209-247.

Othman, R., A. K. A. Domil, Z. C. Senik, N. L. Abdullah, and N. Hamzah. (2006). A case study of balanced scorecard implementation in a Malaysian company. Journal of Asia-Pacific Business 7 (2):55-72.

Pallot, J. (1997). Infrastructure accounting for local authorities: technical management and political context. Financial Accountability \& Management 13 (3):225-242.

- (2001). A decade in review: New Zealand's experience with resource accounting and budgeting. Financial Accountability \& Management 17 (4):383-400.

Parker, L. D., and J. Guthrie. (1993). The Australian public sector in the 1990s: new accountability regimes in motion. Journal of International Accounting, Auditing and Taxation 2 (1):59-81.

Perrin, J. (1998). Resource accounting and budgeting: from cash to accruals in 25 years. Public Money and Management 18 (2):7-10.

Pilcher, R., and G. Dean. (2009). Consequences and costs of financial reporting compliance for local government. European Accounting Review 18 (4):725-744. 
Determining of The Compliance of Local Governments To Implement The Accounting System of The Government's Accrual Base In Indonesia

Probohudono, Widayat, \& Arifah

Rantanen, H., H. I. Kulmala, A. Lönnqvist, and P. Kujansivu. (2007). Performance measurement systems in the Finnish public sector. International Journal of Public Sector Management 20 (5):415-433.

Rutherford, B. A. (2000). The construction and presentation of performance indicators in executive agency external reports. Financial Accountability \& Management 16 (3):225-249.

Ryan, C. (1998). The introduction of accrual reporting policy in the Australian public sector: an agenda setting explanation. Accounting, Auditing \& Accountability Journal 11 (5):518-539.

. (1999). Australian public sector financial reporting: a case of cooperative policy formulation. Accounting, Auditing \& Accountability Journal 12 (5):561-582.

Ryan, C., K. Dunstan, and J. Brown. (2002). The value of public sector annual reports and annual reporting awards in organisational legitimacy. Accounting, Accountability \& Performance 8 (1):61.

Saleh, Z., and M. W. Pendlebury. (2006). Accruals Accounting in Government-Developments in Malaysia. Asia Pacific Business Review 12 (4):421-435.

Shih-Jen, K. H., and L. C. Yee-Ching. (2002). Performance measurement and the implementation of balanced scorecards in municipal governments. The Journal of Government Financial Management 51 (4):8.

Shiraz Rahaman, A. (2009). Independent financial auditing and the crusade against government sector financial mismanagement in Ghana. Qualitative Research in Accounting \& Management 6 (4):224-246.

Siti-Nabiha, A. K., and R. W. Scapens. (2005). Stability and change: an institutionalist study of management accounting change. Accounting, Auditing \& Accountability Journal 18 (1):44-73.

Stanton, P., and J. Stanton. (2002). Corporate annual reports: research perspectives used. Accounting, Auditing \& Accountability Journal 15 (4):478-500.

Suhardjanto, D., and R. R. Yulianingtyas. (2011). Pengaruh karakteristik pemerintah daerah terhadap kepatuhan pengungkapan wajib dalam laporan keuangan pemerintah daerah (Studi empiris pada kabupaten/kota di Indonesia). Jurnal Akuntansi dan Auditing 8 (1):3042.

Ter Bogt, H. J., and G. J. Van Helden. (2000). Accounting change in Dutch government: exploring the gap between expectations and realizations. Management Accounting Research 11 (2):263-279.

Vámosi, T. S. (2000). Continuity and change; management accounting during processes of transition. Management Accounting Research 11 (1):27-63.

Van Peursem, K. A., M. J. Prat, and S. R. Lawrence. (1995). Health management performance: a review of measures and indicators. Accounting, Auditing \& Accountability Journal 8 (5):34-70.

Wilson, C., D. Hagarty, and J. Gauthier. (2004). Results using the balanced scorecard in the public sector. Journal of Corporate Real Estate 6 (1):53-64.

Wisniewski, M., and S. Ólafsson. (2004). Developing balanced scorecards in local authorities: a comparison of experience. International Journal of Productivity and Performance Management 53 (7):602610.

Wisniewski, M., and D. Stewart. (2004). Performance measurementfor stakeholders: The case of Scottish local authorities. International Journal of Public Sector Management 17 (3):222-233.

Zimmerman, J. L. (1977). The municipal accounting maze: An analysis of political incentives. Journal of Accounting Research:107-144. 